\title{
Nanokompozyty na osnowie polipirolu w ochronie metali przed korozją - przegląd literatury
}

\author{
Aleksandra Zaręba ${ }^{1)}$ (NR ORCID: 0000-0002-4511-6870) \\ DOI: dx.doi.org/10.14314/polimery.2021.3.2 \\ Artykut dedykowany Profesor Marii Grzeszczuk z okazji 70. rocznicy urodzin
}

\begin{abstract}
Streszczenie: Korozji, jako procesu korzystnego termodynamicznie, nie można zatrzymać, ponieważ metale występują naturalnie w postaci rud tlenkowych lub soli metali. Dla gospodarki jest to niestety proces kapitałochłonny i niepożądany, jednak z zastosowaniem odpowiednich strategii działania można ograniczyć jego skalę. Niniejszy przegląd literatury, głównie z lat 2018-2020, skupia się na powłokach kompozytowych opartych na polimerze przewodzącym - polipirolu (PPy), wybranych tlenkach metali oraz, ewentualnie, domieszkach surfaktantów i innych związków. Celem pracy jest wykazanie roli polipirolu - polimeru przewodzącego, a przy tym ekologicznego, w ochronie konstrukcji przed korozją metali.
\end{abstract}

Słowa kluczowe: powłoki ochronne, polimer, polipirol, korozja, nanokompozyty.

\section{Nanocomposites on polypyrrole warp in protection metals against corrosion - an overview}

\begin{abstract}
Corrosion cannot be stopped due to its thermodynamically favorable character, since metals occur naturally in the form of oxide ores or metal salts. It is an adverse and capital-intensive process for the economy. However, it can be alleviated by adopting various strategies. This review of the literature, mainly from 2018-2020, focuses on composite coatings based on a conductive polymer - polypyrrole (PPy) and on some metal oxides with the possible use of surfactant admixtures and other compounds. The aim of the study is to emphasize the role of polypyrrole - a conductive and ecological polymer - in the protection of structures against metal corrosion.
\end{abstract}

Keywords: protective coatings, polymer, polypyrrole, corrosion, nanocomposites.

\section{KOROZJA}

Korozja jest zjawiskiem powodującym niszczenie różnorodnych materiałów, w szczególności konstrukcji i przedmiotów metalowych wykonanych zwłaszcza ze stali węglowej. Procesu tego nie da się wyeliminować całkowicie, co przyczynia się do zwiększenia kosztów utrzymywania konstrukcji metalowych w stanie zapewniającym ich właściwe funkcjonowanie i niezagrażającym zdrowiu i życiu człowieka. Proces korozji można jednak znacznie ograniczyć. Korozja stali, przebiegająca głównie w wilgotnym środowisku, ma charakter elektrochemiczny $[1,2]$. Zastosowanie procesów elektrochemicznych w przeciwdziałaniu skutkom korozji jest naturalne i w pełni uzasadnione, ponieważ zmiana potencjału elektrodowego stali umożliwia katodową lub anodową

1) Uniwersytet Wrocławski, Wydział Chemii, F. Joliot-Curie 14, 50-383 Wrocław, Polska.

e-mail: aleksandra.zareba@chem.uni.wroc.pl ochronę, zapobiegającą lub przynajmniej ograniczającą rozpuszczanie stali [1]. W wypadku ochrony protektorowej (katodowej) stal pełni funkcję katody w korozyjnym ogniwie galwanicznym. Wartość potencjału elektrodowego zabezpieczonej stali jest bardziej ujemna niż stali niepokrytej powłoką. Proces rozpuszczania stali jest znacznie ograniczony lub nawet całkowicie zatrzymany. Funkcję protektora pełni, stanowiący anodę w ogniwie mikrokorozyjnym, metal mniej szlachetny niż żelazo. Zniszczenie metalu przebiega zawsze $\mathrm{w}$ obszarze anodowym z jednoczesną depolaryzacją tlenu na katodzie według reakcji $\mathrm{O}_{2}+2 \mathrm{H}_{2} \mathrm{O}+4 \mathrm{e}^{-} \rightarrow 4 \mathrm{OH}^{-} \mathrm{w}$ środowisku zasadowym oraz neutralnym, natomiast $\mathrm{w}$ środowisku kwasowym następuje wydzielanie wodoru na katodzie $2 \mathrm{H}^{+}+2 \mathrm{e}^{-} \rightarrow \mathrm{H}_{2}$ [2].

W wypadku ochrony anodowej potencjał elektrodowy jest przesunięty w kierunku bardziej dodatnich wartości, co prowadzi do pasywacji ograniczającej lub zatrzymującej proces korozji [1]. Zarówno zmiany korozyjne stali, jak i właściwości antykorozyjne powłok można scharaktery- 
zować za pomocą wielu metod elektrochemicznych, chemicznych oraz mikroskopowych. Jedną z takich metod jest elektrochemiczna spektroskopia impedancyjna (EIS), umożliwiająca stwierdzenie występowania kontaktu elektrolitu korozyjnego z podłożem metalicznym pokrytym powłoką antykorozyjną. Wykres Nyquista wykazujący jeden łuk pojemnościowy potwierdza tylko kontakt polimeru powłoki antykorozyjnej z elektrolitem, występujące na wykresie dwa łuki pojemnościowe świadcza o tym, że elektrolit miał kontakt z powierzchnią metalu pod powłoka antykorozyjną, co wskazuje na istnienie ogniwa korozyjnego [3].

Badanie chronoamperometryczne (CA) pozwala na wyznaczenie wartości prądu anodowego - im prąd anody jest mniejszy, tym powłoka ma lepsze właściwości antykorozyjne. Wartość prądu anodowego wyznacza się doświadczalnie, wybierając - na podstawie warunków użytkowania materiału (stali) - odpowiedni roztwór korozyjny, np.: 0,1 M HCl + 0,4 M NaCl (warunki środowiska morskiego). Przyjmuje się, że wartość doświadczalnego prądu anodowego dla stali niezabezpieczonej wynosi $10^{2} \mathrm{~mA} \cdot \mathrm{cm}^{-2}$ [4], wynik poniżej tej wartości, w tym wypadku, oznacza, że powłoka spełnia funkcję ochronna.

Badaniem sprawdzającym ciągłość powłoki ochronnej jest skaningowa mikroskopia elektronowa (SEM), pozwalająca na określenie szczelności warstwy ochronnej, obrazowanie topologii oraz ustalenie składu materiału [5].

\section{POLIPIROL}

Większość znanych polimerów charakteryzuje się właściwościami izolacyjnymi. Jednak część z nich wykazuje także interesujące właściwości przewodzące. Za pionierskie prace nad polimerami przewodzącymi (CP) Heeger, MacDiarmid i Shirakawa zostali wspólnie nagrodzeni Nagrodą Nobla w dziedzinie chemii w 2000 r. Polimery przewodzące otworzyły nową erę rozwoju polimerów. Wyróżniają je zalety, takie jak: niewielka masa, łatwość przetwarzania, odporność na korozję, niski koszt wytwarzania oraz doskonałe właściwości elektryczne, mechaniczne i optyczne [6]. Powłoki ochronne wykonane z polipirolu (PPy) wykazują wyższy potencjał elektrodowy niż stal. Polipirol działa jak bariera zarówno fizyczna, jak i elektroniczna, która stanowi warstwę ochronną przed wpływem agresywnych warunków środowiskowych powodujących korozję [7]. Mechanizm działania bariery fizycznej polega na uniemożliwieniu kontaktu stali ze środowiskiem korozyjnym. Brak pęknięć, otworów i innych wad powłoki gwarantuje skuteczną fizyczną ochronę stali przed korozją [7]. Bariera fizyczna zapobiega dyfuzji jonów i ewentualnych produktów korozji, co utrudnia powstanie miejscowych ogniw korozyjnych [7]. Drugi sposób zapobiegania korozji, możliwy do zrealizowania jedynie z zastosowaniem polimerów przewodzących, do których zalicza się polipirol, polega na utworzeniu warstwy pasywującej na chronionym metalu. Warunkiem skuteczności ochrony jest wyższy potencjał redukcji polimeru takiej warstwy niż chronionego elementu metalowego. Występująca różnica potencjałów redukcji inicjuje reakcję redoks metal-polimer; polipirol utlenia metal do tlenku stanowiącego kolejną warstwę uniemożliwiającą dyfuzję substancji korozjogennych [7].

\section{Metody otrzymywania polipirolowych powłok ochronnych}

Przewodzące powłoki z polipirolu uzyskuje się głównie metodami elektrochemicznymi, na drodze cyklicznej woltamperometrii, chronoamperometrii oraz chronopotencjometrii, prowadzonymi w komórce elektrochemicznej złożonej z trzech elektrod (pracującej, pomocniczej oraz odniesienia). Chronopotencjometria polega na przyłożeniu ze stałą szybkością stałego prądu powodującego polimeryzację monomeru - pirolu [8]. Chronoamperometria wymaga zastosowania stałego potencjału, dostatecznie wysokiego do rozpoczęcia polimeryzacji pirolu i odpowiednio niskiego, niepowodującego nadtlenienia produktu polimeryzacji - polipirolu.

Woltamperometria cykliczna polega na przyłożeniu cyklicznie zmieniającego się potencjału z odpowiednim krokiem w zadanym zakresie, w tzw. oknie potencjałowym [9]. W toku polimeryzacji elektrochemicznej i chemicznej wprowadza się przeciwjony oraz różnorodne inne domieszki poprawiające właściwości antykorozyjne PPy [10].

\section{KOMPOZYTY PPy}

W elektrochemicznym procesie korozji metale oraz ich stopy przekształcają się do najbardziej termodynamicznie stabilnej postaci tlenku lub soli, czyli postaci występującej w naturalnych złożach rud. Otrzymanie czystego metalu lub jego stopu z rudy wymaga nakładu ogromnych ilości energii. Taka sama ilość energii jest uwalniana w reakcji zachodzącej w wyniku kontaktu metalu ze środowiskiem sprzyjającym korozji (obecność wody, tlenu, soli, itp.). To zjawisko, korzystne termodynamicznie dla metalu, stanowi ogromny problem gospodarczy, bowiem korozji nie można zatrzymać. Można jednak ją spowolnić, stosując m.in. powłoki wykonane z kompozytów lub nanokompozytów polipirolu z tlenkami metali, łączące unikatowe, korzystne właściwości składowych materiałów. Przynajmniej jedna faza nanokompozytów ma wymiar nanometryczny. Nanocząstki o dużym stosunku powierzchni do objętości wykazują właściwości odmienne niż taki sam materiał, ale o większych wymiarach cząstek. Wprowadzenie nanocząstek do PPy zwiększa ich pole powierzchni, co ułatwia kontakt elektrochemiczny z substancjami korozjogennymi i chronionym podłożem metalu [11]. Polipirol wykazuje dużą porowatość, przebiegająca wymiana jonowa może więc być niekorzystna, szczególnie w wypadku miejscowej korozji spowodowanej działaniem małych i agresywnych anionów, np. chlorkowych $\left(\mathrm{Cl}^{-}\right)$. Dodatek do PPy nanoczą- 
stek tlenków metali wpływa na uszczelnienie i ujednolicenie powierzchni powłoki wykonanej z kompozytu $\mathrm{PPy}_{\mathrm{A}} \mathrm{Me}_{\mathrm{X}} \mathrm{O}_{\mathrm{Y}}$ [12-14]. Domieszki surfaktantowe [najczęściej używane: sól sodowa kwasu dodecylosiarkowego (SDS), dodecylobenzenosulfonian sodu (SDBS)] mają rozbudowaną strukturę - oba związki zawierają grupę siarczanową oraz przyłączony do niej 12-węglowy „ogon”, SDBS ma dodatkowo grupę fenylową, dzięki czemu dodanie tych surfaktantów do kompozytu tworzącego powłokę ochronną poprawia jej przyleganie do chronionej powierzchni $[15,16]$.

\section{$\mathrm{PPy}-\mathrm{Fe}_{2} \mathrm{O}_{3}$}

Potencjał utlenienia mikrocząstek tlenków żelaza nie przekracza potencjału utlenienia $\mathrm{Fe}^{0}$ do $\mathrm{Fe}^{3+}$, jest więc zbyt niski, aby mogła się utworzyć warstwa pasywacyjna, która składa się z tlenku żelaza(III) [17, 18]. Zmiana wymiarów cząstek $\mathrm{Fe}_{2} \mathrm{O}_{3}, \mathrm{Fe}_{2} \mathrm{O}_{4}$, $\mathrm{z}$ mikro- na nanometryczne, powoduje zwiększenie stosunku ich powierzchni aktywnej do objętości, a tym samym zapewnienie mocy utleniającej wystarczającej do utrzymania polipirolu w stanie utlenionym i powstania pożądanej warstwy pasywacyjnej. Tlenek żelaza $\mathrm{Fe}_{3} \mathrm{O}_{4}$ wykazuje właściwości magnetyczne, które umożliwiają lepsze przyleganie cząstek tego tlenku do powierzchni żelaza i poprawę właściwości ochronnych powłoki [17, 18]. Jadhav i współpr. [12] badali powłoki ochronne wytworzone z ciekłej żywicy epoksydowej (EPON 830), utwardzacza (Epicure 3015), rozpuszczalnika MEK (methyl ethyl ketone - butanon,) oraz pigmentu $\left(\mathrm{Fe}_{2} \mathrm{O}_{3}\right.$ lub $\left.\mathrm{Fe}_{2} \mathrm{O}_{3}+\mathrm{PPy}\right)$. Autorzy przeprowadzili testy na skuteczność ochrony przeciwkorozyjnej metodą elektrochemicznej spektroskopii impedancyjnej (EIS) oraz pomiaru potencjału obwodu otwartego (OCP). Uzyskane wyniki przedstawiono w tabeli 1 [12].

\section{PPy-ZnO}

Cynk stosuje się w antykorozyjnej ochronie konstrukcji stalowych w warunkach atmosferycznych. Nakładany jest na powierzchnię stali metodami: metalizacji natryskowej, zanurzeniowo (ogniowo) lub galwanicznie [19]. Mechanizm ochronny typu protektorowego polega na stworzeniu bariery fizycznej, ochrony elektrochemicznej wynikającej z różnicy potencjałów cynku i chronionej powierzchni, utworzeniu warstwy cynk-patyna. Skuteczność ochrony antykorozyjnej zależy od składu tej warstwy, jej grubości, rozpuszczalności, zwartości oraz przyczepności [20]. Tlenek cynku jest nierozpuszczalny w wodzie, w zależności od środowiska bierze udział w reakcjach, w których wyniku tworzy nierozpuszczane osady $\left[\mathrm{ZnCO}_{3}, \mathrm{Zn}(\mathrm{OH})_{2}\right]$ stanowiące, w czystym środowisku atmosferycznym, szczelną i dobrze przylegającą warstwę antykorozyjną. W warunkach przemysłowych i miejsko-przemysłowych, w środowisku zanieczyszczonym ditlenkiem siarki i chlorkami, powstają związki rozpuszczalne w wodzie, co powoduje rozluźnienie warstwy ochronnej i jej rozszczelnienie i możliwość rozwoju korozji [19]. Zastosowanie kompozytów polimerów przewodzących, w tym z polipirolem, z nanocząstkami tlenku cynku umożliwia poprawę skuteczności ochrony antykorozyjnej w środowisku wody morskiej i w warunkach przemysłowych [13, 20]. Babaei-Sati i współpr. z zastosowaniem elektrochemicznej syntezy uzyskali powłokę kompozytu PPy-ZnO na miękkiej stali. Elektroosadzanie przeprowadzono dwuetapowo. Na pierwszym etapie zastosowano potencjał cykliczny od $-0,5 \mathrm{~V}$ do $1,2 \mathrm{~V}$, a na drugim etapie kontynuowano elektropolimeryzację przy stałym potencjale. Właściwości ochronne powłoki badano w 0,5 M roztworze $\mathrm{H}_{2} \mathrm{SO}_{4}$ metodami polaryzacji Tafela i EIS. W celu określenia morfologii warstwy po testach korozyjnych zbadano ją metodą skaningowej mikroskopii elektronowej (SEM) [20]. Zespół Rajkumara [21] otrzymał kompozyt PPy-ZnO z żywicą akrylową. Polimer PPy uzyskano na drodze chemoutleniającej polimeryzacji pirolu (utleniacz $\mathrm{FeCl}_{3}$ ) z domieszką surfaktantu SDS (dodecylosulfanian sodu). W toku polimeryzacji do mieszaniny reakcyjnej dodano nanocząstki ZnO; wytworzony kompozyt wymieszano z żywicą akrylową. Metodami spektroskopii IR z transformatą Fouriera (FT-IR), spektroskopii UV, dyfrakcji promieniowania rentgenowskiego (XRD - X-ray diffraction), spektroskopii rentgenowskiej z dyspersją energii (EDS - Energy Dispersive X-ray Spectroscopy) potwierdzono wprowadzenie nanocząstek $\mathrm{ZnO}$ do osnowy polipirolowej. Metodami elektrochemicznymi (EIS, metodą polaryzacji) oceniono, że odporność na korozję powłok nanokompozytowych PPy-ZnO-żywica akrylowa się zwiększyła w stosunku do odporności na korozję powłoki PPy-żywica akrylowa [21].

\section{$\mathrm{PPy}_{-\mathrm{TiO}}$}

Komponenty kompozytu $\mathrm{PPy}^{-\mathrm{TiO}_{2}}$ tworzą łącze typu p-n, gdzie polipirol pełni funkcję półprzewodnika typu p o przewodnictwie dziurowym w paśmie walencyjnym, natomiast tlenek tytanu $\mathrm{TiO}_{2}$ przewodzi elektronowo. Łącze p-n stanowi istotną barierę dla ruchu elektronów i wymusza ich jednostronny transport w kierunku $\mathrm{TiO}_{2}$ co powoduje akumulację ładunku w złączu. Następuje zwiększenie pojemności warstwy podwójnej pomiędzy metalem a warstwą ochronną, co przyczynia się do spowolnienia reakcji anodowej roztwarzania stali $\left(\mathrm{Fe} \rightarrow \mathrm{Fe}^{2+}+2 \mathrm{e}\right)$. Zastosowanie tlenku tytanu, taniego i odpornego na korozję napełniacza zmniejszającego porowatość PPy (wydaje się, że polipirol w hybrydowych materiałach $\mathrm{TiO}_{2}$ pełni głównie rolę spoiwa nanokrystalitów tlenku [22]) powoduje zwiększenie szczelności powłoki antykorozyjnej [7]. Rajkumar i współpr. [21] otrzymali kompozyt polipirolu z nanocząstkami $\mathrm{TiO}_{2^{\prime}}$ w sposób analogiczny jak kompozyt z tlenkiem cynku. Potwierdzono wprowadzenie nanocząstek do matrycy PPy, przeprowadzono też testy korozyjne [21]. Babaei-Sati i współpr. [20] uzyskali kompozyt polipirolu z nano- 
T a b e 1 a 1. Porównanie badań korozyjnych w środowisku morskim i przemysłowym

$\mathrm{T}$ a b 1 e 1. Comparative of corrosion tests in sea and industrial environment

\begin{tabular}{|c|c|c|c|c|c|c|c|}
\hline \multirow{3}{*}{$\begin{array}{l}\text { Powłoka } \\
\text { ochronna }\end{array}$} & \multicolumn{5}{|c|}{ Środowisko korozyjne morskie } & \multirow{3}{*}{$\begin{array}{l}\text { Roztwór } \\
\text { korozyjny }\end{array}$} & \multirow{3}{*}{ Ref. } \\
\hline & \multirow[b]{2}{*}{ Typ stali } & \multirow{2}{*}{$\begin{array}{c}R_{\text {corr }} \\
\Omega \mathrm{cm}^{2}\end{array}$} & \multirow{2}{*}{$\begin{array}{c}\mathrm{OCP} \\
\mathrm{V}\end{array}$} & \multicolumn{2}{|c|}{ Tafel } & & \\
\hline & & & & $\begin{array}{c}I_{\text {corr }} \\
\mathrm{A} / \mathrm{cm}^{2}\end{array}$ & $E_{\mathrm{corr}}$ & & \\
\hline \multicolumn{8}{|c|}{ Żywica akrylowa (akryl) } \\
\hline Akryl & CS & 18,82 & - & 0,0254 & $-0,520$ & $1 \% \mathrm{HCl}$ & [21] \\
\hline PPy & CS & 24,22 & - & 0,0190 & $-0,502$ & $1 \% \mathrm{HCl}$ & [21] \\
\hline PPy-ZnO & CS & 45,58 & - & 0,0120 & $-0,411$ & $1 \% \mathrm{HCl}$ & [21] \\
\hline $\mathrm{PPy}-\mathrm{TiO}_{2}$ & CS & 61,60 & - & 0,0079 & $-0,448$ & $1 \% \mathrm{HCl}$ & {$[21]$} \\
\hline PPy-SiO2 & CS & 33,88 & - & 0,0142 & $-0,474$ & $1 \% \mathrm{HCl}$ & [21] \\
\hline Akryl & CS & 65,62 & - & 0,0068 & $-0,729$ & $3,5 \% \mathrm{NaCl}$ & {$[21]$} \\
\hline PPy & CS & 110,44 & - & 0,0037 & $-0,688$ & $3,5 \% \mathrm{NaCl}$ & [21] \\
\hline PPy-ZnO & CS & 270,62 & - & 0,0018 & $-0,492$ & $3,5 \% \mathrm{NaCl}$ & [21] \\
\hline $\mathrm{PPy} \mathrm{TiO}_{2}$ & CS & 391,30 & - & 0,0012 & $-0,571$ & $3,5 \% \mathrm{NaCl}$ & {$[21]$} \\
\hline $\mathrm{PPy}-\mathrm{SiO}_{2}$ & CS & 179,53 & - & 0,0022 & $-0,628$ & $3,5 \% \mathrm{NaCl}$ & [22] \\
\hline \multicolumn{8}{|c|}{ Bez żywicy akrylowej } \\
\hline $\mathrm{PPy}-\mathrm{Al}_{2} \mathrm{O}_{3}$ & 316SS & - & - & $.0,008$ & - & $3,5 \% \mathrm{NaCl}$ & [23] \\
\hline PPy-ZnO & AA2024Al & 656 & - & - & $-0,720$ & $3.5 \% \mathrm{NaCl}$ & [24] \\
\hline \multicolumn{8}{|c|}{ PBV } \\
\hline PBV & CS & - & $-0,400$ & - & - & $3 \% \mathrm{NaCl}$ & [25] \\
\hline $\mathrm{SiO}_{2}$ & $\mathrm{CS}$ & - & $-0,320$ & - & - & $3 \% \mathrm{NaCl}$ & [25] \\
\hline PPy-SiO 2 & CS & - & 0,010 & - & - & $3 \% \mathrm{NaCl}$ & [25] \\
\hline${\mathrm{PPyOX}-\mathrm{SiO}_{2}}_{2}$ & CS & - & 0,090 & - & - & $3 \% \mathrm{NaCl}$ & [25] \\
\hline \multicolumn{8}{|c|}{ Żywica epoksydowa } \\
\hline $\mathrm{EP}$ & CS & - & $-0,300$ & - & - & $3 \% \mathrm{NaCl}$ & [26] \\
\hline PPyOX-SiO 2 & CS & - & 0,200 & - & - & $3 \% \mathrm{NaCl}$ & [26] \\
\hline \multicolumn{8}{|c|}{ Środowisko korozyjne przemysłowe } \\
\hline- & MS & 0,8 & - & 0,00148 & $-0,512$ & $0,5 \mathrm{M} \mathrm{H}_{2} \mathrm{SO}_{4}$ & [20] \\
\hline PPy & MS & 26,9 & - & 0,00054 & $-0,532$ & $0,5 \mathrm{M} \mathrm{H}_{2} \mathrm{SO}_{4}$ & [20] \\
\hline PPy-ZnO & MS & 119,3 & - & 0,000121 & $-0,533$ & $0,5 \mathrm{M} \mathrm{H}_{2} \mathrm{SO}_{4}$ & [20] \\
\hline $\mathrm{PPy}^{-\mathrm{TiO}_{2}}$ & MS & 95,5 & - & 0,000144 & $-0,510$ & $0,5 \mathrm{M} \mathrm{H}_{2} \mathrm{SO}_{4}$ & [20] \\
\hline $\mathrm{PPy}-\mathrm{nAl}_{2} \mathrm{O}_{3}$ & MS & 277,4 & - & 0,000082 & $-0,525$ & $0,5 \mathrm{M} \mathrm{H}_{2} \mathrm{SO}_{4}$ & [20] \\
\hline $\mathrm{PPy}-\mu \mathrm{Al}_{2} \mathrm{O}_{3}$ & MS & 81,0 & - & 0,00030 & $-0,550$ & $0,5 \mathrm{M} \mathrm{H}_{2} \mathrm{SO}_{4}$ & [20] \\
\hline
\end{tabular}

A2024Al - stop aluminium, MS - stal miękka, CS - stal węglowa, 316SS - stal nierdzewna

cząstkami $\mathrm{TiO}_{2}$ metodą elektrochemiczną w środowisku kwasu szczawiowego na dwóch etapach, z zastosowaniem potencjału cyklicznego od $-0,5 \mathrm{~V}$ do $1,2 \mathrm{~V}$, a następnie potencjału o stałej wartości. Kompozyt $\mathrm{PPy}_{-} \mathrm{TiO}_{2}$ poddano badaniom SEM, krzywych polaryzacji i EIS [20].

$$
\mathrm{PPy}-\mathrm{Al}_{2} \mathrm{O}_{3}
$$

Tlenek glinu $\mathrm{Al}_{2} \mathrm{O}_{3}$, ze względu na niski koszt wytwarzania, dużą stabilność chemiczną i skuteczność ochrony fizycznej, jest chętnie stosowany w powłokach ochronnych [20]. Jednak poważne problemy techniczne są związane $\mathrm{z}$ uzyskaniem stabilnej dyspersji cząstek $\mathrm{Al}_{2} \mathrm{O}_{3}$ oraz włączeniem ich do osnowy polimerowej. Yan i współpr.
[20] zaproponowali dwuetapową procedurę otrzymywania kompozytu $\mathrm{PPy}_{-} \mathrm{Al}_{2} \mathrm{O}_{3}$. Na pierwszym etapie utworzono układ koloidalny (zol izopropanolanu glinu, dejonizowanej wody i kwasu $p$-toluenosulfonowego), następnie $\mathrm{w}$ wyniku polimeryzacji elektrochemicznej uzyskano kompozytowy żel polipirolu. Materiał badano metodami SEM i FT-IR, OCP w funkcji czasu, wyznaczono krzywe polaryzacji Tafela i EIS [23]. Babaei-Sati i współpr. [20] uzyskali kompozyt polipirolu z nanocząstkami $\mathrm{Al}_{2} \mathrm{O}_{3}$ $\mathrm{w}$ wyniku elektropolimeryzacji $\mathrm{w}$ środowisku kwasu szczawiowego na dwóch etapach: z zastosowaniem potencjału cyklicznego od $-0,5 \mathrm{~V}$ do $1,2 \mathrm{~V}$, a następnie potencjału stałego. Otrzymany materiał badano metodac SEM, przeprowadzono test Tafela i EIS [20]. 


\section{$\mathrm{PPy}_{-} \mathrm{SiO}_{2}$}

Nanokompozyty $\mathrm{PPy}_{-} \mathrm{SiO}_{2}$, ze względu na małokosztowe komponenty, rozwiniętą powierzchnię krzemionki, wynikającą z jej chropowatości, oraz łatwość dyspersji znajdują zastosowanie $\mathrm{w}$ tworzeniu powłok antykorozyjnych do ochrony stali [25]. Van i współpr. uzyskali kompozyty PVB-PPy-SiO ${ }_{2}$ (bez dodatku szczawianu sodu) (PVB - poliwinylobutyral) oraz PVB-PPyOX-SiO ${ }_{2}$ (z dodatkiem szczawianu sodu jako dodatkowym utleniaczem) (PPyOX - utleniony polipirol) metodą chemicznego utleniania z zastosowaniem $\mathrm{FeCl}_{3}$ i następnego mieszania odpowiedniego półproduktu z żywicą PVB. Do charakterystyki materiałów wykorzystano metody elektrochemiczne (OCP, EIS), spektroskopowe (FT-IR), mikroskopowe (SEM, TEM) i termiczne (TGA) [25]. Wytworzone kompozyty $\mathrm{PPy}-\mathrm{SiO}_{2}$ oraz $\mathrm{PPyOX}-\mathrm{SiO}_{2}$, będące przedmiotem opracowania Van V. i współpr. [25], zmieszano, zamiast z PVB, z żywicami epoksydowymi. Warstwy kompozytów nanoszono na chronione powierzchnie za pomocą powlekarki wirówkowej, po czym badano je metodami: TGA, TEM, EDS, EIS i OCP [26]. Zespół Rajkumara [21] otrzymał kompozyt polipirolu z $\mathrm{SiO}_{2}$ i żywicą akrylową na drodze chemicznej polimeryzacji $\mathrm{w}$ obecności utleniacza $\mathrm{FeCl}_{3}$ i domieszką surfaktantu SDS. W toku polimeryzacji do mieszaniny reakcyjnej dodano nanocząstki $\mathrm{SiO}_{2^{\prime}}$ a uzyskany kompozyt wymieszano z żywicą akrylową. Wykonano pomiary EIS i sporządzono wykresy Tafela wytworzonej powłoki [21].

\section{PODSUMOWANIE}

Brak wyznaczonych przez autorów [12] wartości potencjału korozyjnego $\left(E_{\text {corr }}\right)$ i prądu korozyjnego $\left(I_{\text {corr }}\right)$ powłok wytworzonych z kompozytów $\mathrm{Fe}_{2} \mathrm{O}_{3}$ i $\mathrm{Fe}_{2} \mathrm{O}_{3}$-PPy utrudnia porównanie ich z powłokami otrzymanymi z innych kompozytów. Badanie EIS w teście mgły solnej powłok wykonanych z $\mathrm{Fe}_{2} \mathrm{O}_{3}$ i $\mathrm{Fe}_{2} \mathrm{O}_{3}$-PPy wykazało spadek impedancji przy niskiej częstotliwości zaburzenia AC (zasilanie prądem zmiennym). Zmiana ta oznacza wnikanie elektrolitu przez rozwinięte pory w powłoce, a w konsekwencji zmniejszenie skuteczności ochrony [12]. Badanie EIS wskazało także początek reakcji korozji w powłoce $\mathrm{Fe}_{2} \mathrm{O}_{3}$ oraz kontakt elektrolitu korozyjnego z warstwą chronionej stali. Na podstawie wyników badania EIS i OCP stwierdzono, że obecność polipirolu w materiale powłoki poprawiła jej właściwości antykorozyjne. Polipirol w powłoce $\mathrm{Fe}_{2} \mathrm{O}_{3}$-PPy spełnia rolę utleniacza w reakcji pasywacji podłoża stalowego [12]. Na podstawie wyników badań kompozytów $\mathrm{PPyOX}-\mathrm{SiO}_{2} \mathrm{i} \mathrm{PPy}-\mathrm{SiO}_{2}$ na osnowie różnych żywic epoksydowych [23] oraz PBV [26] można wybrać najlepszy materiał kompozytowy, jednak ze względu na brak wartości $E_{\text {corr }}$ i $I_{\text {corr }}$ (podano wartość OCP) nie można go porównać z materiałami innych powłok ochronnych zestawionych $\mathrm{w}$ tabeli 1 , dla których wyznaczono wartości $E_{\text {corr }}$ i $I_{\text {corr }}$ natomiast nie podano wartości OCP.
Na bazie istniejących danych literaturowych nie można wskazać uniwersalnej powłoki, która chroniłaby metal przed korozją we wszystkich środowiskach. W środowisku morskim $(1 \% \mathrm{HCl}, 3.5 \%$ lub 3\% roztwór $\mathrm{NaCl}$ ) najefektywniejsza jest powłoka wykonana z kompozytu żywica akrylowa-PPy-TiO ${ }_{2}$ ponieważ $\mathrm{w}$ teście Tafela w takich warunkach wykazuje największą wartość $R_{\text {corr }}$ (opór przy potencjale $E_{\text {corr }}$ ) i najmniejszą wartość $I_{\text {corr }}$ Elektrochemiczne pomiary korozji i test zanurzeniowy wytworzonych powłok pokazują, że wprowadzenie nanocząstek tlenku metalu $\mathrm{w}$ istotnym stopniu poprawia właściwości ochronne antykorozyjnej powłoki PPy. Wspomniana powłoka wykonana $\mathrm{z}$ nanokompozytu żywicy akrylowej-PPy-TiO ${ }_{2}$ swoje antykorozyjne właściwości uzyskała dzięki dodatkowi $\mathrm{TiO}_{2}$, nanocząstki $\mathrm{TiO}_{2}$ wniknęły w pory polimeru, a otrzymana folia uzyskała zwartą i szczelną strukturę [21]. W środowisku przemysłowym (roztwór 0,5 $\mathrm{M} \mathrm{H}_{2} \mathrm{SO}_{4}$ ) funkcje ochronne najlepiej spełnia kompozyt $\mathrm{PPy}_{-} \mathrm{Al}_{2} \mathrm{O}_{3}$, ponieważ w tych warunkach wykazuje on największą wartość $R_{\text {corr }}$ i najmniejszą $I_{\text {corr }}$. Mechanizm ochronny jest podobny jak w wypadku kompozytu z tlenkiem tytanu. W środowisku przemysłowym nanocząstki tlenku glinu w zastosowanej powłoce dodatkowo powodują jej pasywację w kontakcie z kwasem siarkowym. Wykazano, że trudno znaleźć skuteczną i uniwersalną dla wszystkich środowisk powłokę ochronną metali. Problem ten wciąż pozostaje otwarty.

\section{LITERATURA}

[1] Wranglén G.: „Podstawy korozji i ochrony metali”, Wydawnictwa Naukowo-Techniczne, 1985, str. 212, 213.

[2] Surowska B.: „Wybrane zagadnienia z korozji i ochrony przed korozją", Politechnika Lubelska, Lublin 2002, str. 7.

[3] Ding Y., Zhong J., Xie P. i in.: Polymers 2019, 11, 1998. https://doi.org/10.3390/polym11121998

[4] Malik M.A., Kulesza P.J., Wlodarczyk R. i in.: Journal of Solid State Electrochemistry 2005, 9, 403. https://doi.org/10.1007/s10008-005-0654-x

[5] Łapkowski M.: Polimery 1986, 31, 407. https://doi.org/10.14314/polimery.1986.407

[6] Pokrop R., Zagórska M., Kulik M. i in.: Molecular Crystals and Liquid Crystals 2004, 415, 93. https://doi.org/10.1080/15421400490482934

[7] Ashassi-Sorkhabi H., Kazempour A.: Journal of Molecular Liquids 2020, 309, 85. https://doi.org/10.1016/j.molliq.2020.113085

[8] Ashassi-Sorkhabi H., Kazempour A.: Carbohydrate Polymers 2020, 237, 110. https://doi.org/10.1016/j.carbpol.2020.116110

[9] De Leon A., Advincula R.C.: Intelligent Coatings for Corrosion Control 2015, 409. http://dx.doi.org/10.1016/B978-0-12-411467-8.00011-8

[10] Rabek J.F.: „Współczesna wiedza o polimerach t. 2”, PWN, Warszawa 2017, str. 431. 
[11] Arabzadeh H., Shahidi M., Foroughi M.M.: Journal of Electroanalytical Chemistry 2017, 807, 162. https://doi.org/10.1016/j.jelechem.2017.11.019

[12] Jadhav N., Kasisomayajula S., Johnston V.G.: Frontiens in Materials 2020, 7, 95. https://doi.org/10.3389/fmats.2020.00095

[13] Hosseini M.G., Bagheri R., Najjar R.: Journal of Applied Polymer Science 2011, 121, 3159. https://doi.org/10.1002/app.33952

[14] Chen Z., Yang W., Xu B. i in.: Progress in Organic Coatings 2018, 122, 159. https://doi.org/10.1016/j.porgcoat.2018.05.022

[15] Nautiyal A., Qiao M., Cook J.E. i in.: Applied Surface Science, Part A 2018, 427, 922. http://dx.doi.org/10.1016/j.apsusc.2017.08.093 01694332

[16] Bayat M., Izadan H., Molina B. i in.: Polymers 2019, 11, 1757. https://doi.org/10.3390/polym11111757

[17] Garcia B., Lamzoudi A., Pillier F. i in.: Journal of The Electrochemical Society 2002, 149, B560. https://doi.org/10.1149/1.1517581

[18] Pailleret A., Hien N.T.L., Thanh D.T.M. i in.: Journal of Solid State Electrochemistry 2007, 11, 1013. https://doi.org/10.1007/s10008-007-0262-z
[19] Głuszko M.: „Zagadnienia ochrony antykorozyjnej konstrukcji stalowych oraz urządzeń elektroenergetycznych eksploatowanych w warunkach atmosferycznych", IEl, Warszawa 2008, str. 19.

[20] Babaei-Sati R., Parsa J.B., Vakili-Azghandi M.: Synthetic Metals 2019, 247, 183.

https://doi.org/10.1016/j.synthmet.2018.12.009

[21] Rajkumar R., Vedhi C.: Anti-Corrosion Methods and Materials 2020, 67, 305.

https://doi.org/10.1108/ACMM-11-2019-2204

[22] Dziewoński P.M., Grzeszczuk M.: Electrochimica Acta 2010, 55, 3336. https://doi.org/10.1016/j.electacta.2010.01.043

[23] Yan Q., Li C., Huang T. i in.: AIP Conference Proceedings, AIP Publishing 2017, 1820, 30005. http://dx.doi.org/10.1063/1.4977262

[24] Fekri F., Zandi M.S.,Foroughi M.M.: Iranian Polymer Journal 2019, 28, 577. https://doi.org/10.1007/s13726-019-00726-2

[25] Van V.T.H., Hang T.T.X., Thi P.: Journal of Nanoscience and Nanotechnology 2018, 18, 4189. http://dx.doi.org/10.1166/jnn.2018.15198

[26] Vu V.T.H., Dinh T.T.M., Pham N.T. i in.: International Journal of Corrosion 2018, ID 6395803. https://doi.org/10.1155/2018/6395803

Otrzymano 11 IX 2020 r.
Katedra Inżynierii i Technologii Polimerów

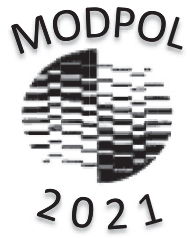

Wydział Chemiczny

Politechniki Wrocławskiej

zapraszaja do udziału w

XXV Konferencji Naukowej MODYFIKACJA POLIMERÓW

\section{6-9 września 2021 r.}

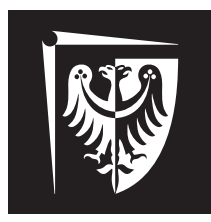

Politechnika Wrocławska

Przewodniczący Konferencji i Komitetu Organizacyjnego: prof. dr hab. inż. Andrzej TROCHIMCZUK

Sekretarz Konferencji: dr inż. Sylwia RONKA

Konferencja będzie poświęcona multidyscyplinarnym zagadnieniom związanym z polimerami począwszy od podstawowej syntezy i metodologii do nanoskali i materiałów inspirowanych polimerami naturalnymi

\section{Tematyka konferencji:}

- Modyfikacja chemiczna i fizyczna oraz reaktywne przetwarzanie polimerów

- Synteza, struktura i morfologia polimerów

- Kompozyty i Nanokompozyty polimerowe

- Biomateriały i ich zastosowanie biomedyczne

- Materiały kompozytowe reagujące na bodźce
- Tworzywa polimerowe z surowców odnawialnych i wtórnych

- Biodegradowalne polimery i strategia recyklingu

- Nowe zastosowania oraz metody badań i właściwości polimerów

Szczegółowe informacje już wkrótce na stronie internetowej katedry.

Kontakt: emilia.zachanowicz@pwr.edu.pl, tel. 661674446 